\title{
PENGARUH SUHU DAN WAKTU PASTEURISASI TERHADAP PERUBAHAN \\ KADAR TOTAL FENOL PADA WEDANG UWUH READY TO DRINK DAN \\ KINETIKA PERUBAHAN KADAR TOTAL FENOL SELAMA PENYIMPANAN
}

\section{EFFECT OF TEMPERATURE AND TIME PASTEURIZATION ON TOTAL PHENOLIC CONTENT IN WEDANG UWUH READY TO DRINK AND KINETICS CHANGES OF TOTAL PHENOLIC CONTENT DURING STORAGE}

\author{
Landep Wisnu $1^{1)}$, Kawiji $2^{1)}$, Windi Atmaka $3^{1)}$ \\ ${ }^{1)}$ Ilmu dan Teknologi Pangan, Universitas Sebelas Maret, Surakarta \\ email: landep.ldp5@gmail.com
}

\begin{abstract}
Indonesia's spice is a plant herbs that are useful for health. Traditional drink using several spices indonesia is wedang uwuh. Wedang uwuh consisting of ginger, wood shavings secang, leaves pala, leaves cinnamon, twigs cengkeh, leaves of the pandanus, and sugar stone. Wedang uwuh could give the health effects, due to the antioxidant content. Antioxidants can neutralize and destroy free radicals that may cause damage to cells and biomolecules. Wedang uwuh with the treatment of pasteurization is one of the techniques to make wedang uwuh more interesting, easily served and durable. This research aimed to determine total phenol content that could be preserved after the pasteurization treatment and also choose which pasteurization method could preserve the most total phenol content. In addition, the purpose of this research was to know the kinetics of phenol content changes during storage $\left(8-10^{\circ} \mathrm{C}\right)$. The experimental design used in this study was a randomized Complete Design (RAL) with two factors, each factor consists of 3 levels. The first factor is the temperature of pasteurization, consisting of 3 level temperature of $65^{\circ} \mathrm{C}, 75^{\circ} \mathrm{C}, 85^{\circ} \mathrm{C}$ and the second factor is time pasteurization, consisting of three levels: 10, 20, 30 minutes with two sample repetitions. Processing the data using analysis of ANOVA show research results 9 combination treatment of pasteurization temperature and time has no effect on the total phenol content of real wedang uwuh. Results of the kinetic data processing changes the levels of total phenols during cold temperature storage of $8-10^{\circ} \mathrm{C}$ showed no significant change.
\end{abstract}

Keywords: free radicals, phenol, ready to drink, wedang uwuh

\begin{abstract}
ABSTRAK
Rempah-rempah di Indonesia telah dikenal sebagai tanaman herbal yang bermanfaat bagi kesehatan. Salah satu produk minuman tradisional yang menggunakan beberapa rempah-rempah khas Indonesia adalah wedang uwuh. Wedang Uwuh adalah minuman yang berbahan dasar jahe, serutan kayu secang, daun pala, daun kayu manis, ranting cengkeh, daun pandan, dan gula batu. Wedang uwuh diketahui bisa memberikan efek kesehatan, karena kandungan senyawa aktif didalamnya yaitu antioksidan. Peranan antioksidan sangat penting dalam menetralkan dan menghancurkan radikal bebas yang dapat menyebabkan kerusakan sel dan juga merusak biomolekul. Wedang uwuh ready to drink dengan perlakuan pasteurisasi adalah salah satu teknik untuk membuat wedang uwuh lebih menarik, mudah disajikan dan tentunya tahan lama. Tujuan dari penelitian ini adalah untuk mengetahui pengaruh suhu dan waktu pasteurisasi terhadap kandungan fenol yang terdapat dalam wedang uwuh dan untuk mengetahui kinetika perubahan kadar total fenol selama penyimpanan suhu rendah 8$10^{\circ} \mathrm{C}$. Rancangan percobaan yang digunakan dalam penelitian ini adalah Rancangan Acak Lengkap (RAL) dengan dua faktor, masing-masing faktor terdiri dari 3 level. Faktor yang pertama suhu pasteurisasi, terdiri dari 3 level suhu yaitu $65^{\circ} \mathrm{C}, 75^{\circ} \mathrm{C}, 85^{\circ} \mathrm{C}$ dan faktor yang kedua waktu pasteurisasi, terdiri dari 3 level yaitu $10,20,30$ menit dengan perulangan sampel sebanyak dua kali. Pengolahan data menggunakan analisis ragam ANOVA menunjukkan hasil penelitian 9 kombinasi perlakuan suhu dan waktu pasteurisasi tidak berpengaruh nyata terhadap kandungan total fenol wedang uwuh. Hasil pengolahan data kinetika perubahan kadar total fenol selama penyimpanan suhu dingin $8-10^{\circ} \mathrm{C}$ tidak menunjukkan perubahan yang signifikan/nyata.
\end{abstract}

Kata Kunci : fenol, pasteurisasi, radikal bebas, ready to drink, wedang uwuh

\section{PENDAHULUAN}

Tren minuman fungsional sedang diminati oleh konsumen karena dipercaya berkhasiat bagi kesehatan. Sebagian besar minuman fungsional tersebut terbuat dari kombinasi bahan rempah-rempah tradisional. Beberapa contoh hasil kajian formulasi minuman fungsional tradisional yang terbukti memiliki khasiat bagi kesehatan antara lain : bir pletok (Dulimarta, 2000), minuman madai, (Girsang, 2003), serta minuman 
fungsional tradisional berbasis jahe seperti wedang jahe, bajigur, sekoteng, bandrek, dan serbat. Pengembangan formulasi minuman menjadi penting untuk keperluan manufacturing sehingga dapat menghasilkan pangan fungsional yang bisa diterima oleh masyarakat dari segi sensorinya. Pencampuran rempah-rempah dalam formulasi minuman dapat dilakukan untuk memperoleh suatu kombinasi antioksidan (aspek fisiologikal) dengan aktivitas yang lebih tinggi dibandingkan jika hanya digunakan secara terpisah/tunggal (Herold, 2007).

Salah satu produk minuman tradisional yang kaya akan antioksidan adalah wedang uwuh. Wedang uwuh merupakan minuman tradisional warisan para raja. Terbuat dari ramuan rempah-rempah alami dan menebarkan aroma yang mudah menggugah selera. Merupakan salah satu minuman kesehatan tradisional yang kaya antioksidan dan minyak atsiri. Khasiatnya pun banyak, dapat menambah stamina tubuh, menghangatkan badan, dan menghilangkan lelah serta mencegah radang tenggorokan. Bahan-bahan pembuatan wedang uwuh sendiri sangat berlimpah sumbernya, yaitu terdiri dari daun cengkeh, daun pala, jahe, serutan kayu secang, dan gula batu (PDN, 2012).

Pada penelitian yang dilakukan oleh (Nirmagustina, dkk) terhadap minuman secang menunjukkan bahwa kadar total fenol pada minuman secang lebih tinggi ketika secang diformulasikan dengan rempahrempah lain seperti jahe merah, sereh, cengkeh, kayu manis, kapulaga, dan pala. Pada hasil pengamatannya formula minuman yang hanya menggunakan secang saja, kandungan total fenolnya sebesar 117,989 $\mathrm{mg} / \mathrm{L}$. Sedangkan pada formulasi yang menggunakan berbagai rempah-rempah (secang, jahe merah, sereh, cengkeh, kayu manis, kapulaga, dan pala), kandungan total fenolnya sebesar $186,056 \mathrm{mg} / \mathrm{L}$. Hal ini menunjukkan bahwa minuman tradisional wedang uwuh yang menggunakan berbagai rempah di dalam formulasi minumannya, memiliki potensi sebagai pangan fungsional, yaitu minuman kaya antioksidan.
Selama ini, selain disajikan dalam bentuk seduhan siap minum, wedang uwuh juga dijual dalam bentuk kemasan. Kemasan wedang uwuh sangat sederhana, hanya berupa komponen kering yang dibungkus plastik. Sayangnya kemasan wedang uwuh ini kurang menarik, penyajiannya agak merepotkan dan tidak tahan disimpan dalam waktu yang agak lama, sehingga nilai ekonomi dari wedang uwuh kemasan plastik ini masih rendah. Oleh karena itu diperlukan pengembangan teknik baru untuk menyajikan wedang uwuh dalam bentuk yang lebih menarik, awet dan mudah disajikan. Salah satu usaha untuk menyajikan wedang uwuh yang lebih menarik, awet dan mudah disajikan adalah dengan cara membuatnya menjadi wedang uwuh dalam kemasan gelas/cup.

Untuk memperpanjang umur simpan wedang uwuh dalam kemasan ready to drink, maka perlu dilakukannya pasteurisasi. Pasteurisasi adalah proses pemanasan untuk memperpanjang umur simpan bahan pangan melalui pemanasan pada suhu 60$100^{\circ} \mathrm{C}$ yang bertujuan untuk membunuh mikroorganisme seperti bakteri, kapang dan khamir serta menginaktivasi enzim yang terdapat dalam bahan pangan itu sendiri dengan masih mempertimbangkan mutunya (Fellow, 1992).

\section{METODE PENELITIAN}

\section{Bahan dan Alat}

Bahan-bahan untuk pembuatan minuman tradisional dalam penelitian ini adalah wedang uwuh seduh yang diperoleh dari Pasar Gede Surakarta dan air minum dalam kemasan merk "Aqua". Sedangkan bahan-bahan yang digunakan untuk analisis antara lain aquades, reagen Folin ciocalteu, natrium karbonat $\left(\mathrm{Na}_{2} \mathrm{CO}_{3}\right)$, fenol murni, $\mathrm{PCA}, \mathrm{NaCl}$.

Alat-alat yang digunakan untuk pembuatan wedang uwuh yaitu timbangan analitik, spatula, panci, kompor gas, saringan, alumunium foil, baskom, gelas plastik PP, mesin sealer, waterbath, termometer, penjepit kayu, stopwatch. Peralatan untuk analisis antara lain gelas beker, erlenmeyer, labu takar $100 \mathrm{ml}$, labu takar $50 \mathrm{ml}$, propipet, pipet 
volume, tabung reaksi, rak tabung reaksi, vortex, spektrofotometer UV-vis, kuvet, termometer, cawan petri, erlenmeyer dan peralatan gelas.

\section{Tahapan Penelitian}

\section{Pembuatan Wedang Uwuh Siap Minum}

Semua bahan-bahan wedang uwuh (jahe yang sudah dimemarkan, serutan secang, daun kayu manis, daun cengkeh, ranting cengkeh, daun pandan, gula batu) dalam bentuk kering siap seduh dimasukkan dalam panci (tanpa gula) kemudian diseduh air mendidih $\pm 100^{\circ} \mathrm{C}$, diaduk, dan didiamkan sekitar 15 menit agar keluar ekstraknya (Hartanto, 2012; Tasia, 2014). Gula batu diseduh secara terpisah menggunakan air mendidih sampai larut. Masing-masing seduhan tersebut disaring dan dicampurkan. Setelah itu, dikemas dalam gelas-gelas plastik jenis Polyprophilene (PP) kemudian direkatkan plastik penutup menggunakan mesin cup sealer. Selanjutnya dipasteurisasi dengan kombinasi variasi suhu $(65,75$, dan $\left.85{ }^{\circ} \mathrm{C}\right)$ dan waktu $(10,20,30$ menit). Lalu produk direndam dalam icebath \pm 10 menit

\section{Analisa Kadar Total Fenol}

Sebanyak $5 \mathrm{ml}$ minuman dimasukkan ke dalam labu takar $50 \mathrm{ml}$, ditambahkan aquades sampai tanda tera, digojog sampai homogen. Kemudian diambil $1 \mathrm{ml}$ larutan dimasukkan ke dalam tabung reaksi, ditambahkan $5 \mathrm{ml} \mathrm{Na}_{2} \mathrm{CO}_{3}(2 \%)$, diamkan selama 10 menit. Setelah itu ke dalam tabung reaksi ditambahkan $0,5 \mathrm{ml}$ reagen Folin ciocalteau, dan divortek, diamkan selama 30 menit kemudian diukur nilai absorbansinya pada panjang gelombang $750 \mathrm{~nm}$. Kurva standar dibuat dengan cara yang sama dengan mengganti sampel dengan fenol murni yang dibuat dalam beberapa konsentrasi dari $0-50$ ppm. Kandungan total fenol dalam minuman wedang uwuh dinyatakan dalam satuan part per million (ppm).

Analisa kinetika perubahan total fenol dan jumlah mikroba wedang uwuh selama penyimpanan.

Pada analisa total fenol dengan variasi waktu dan suhu pasteurisasi didapatkan kombinasi waktu dan suhu pasteurisasi yang terbaik untuk mempertahankan kandungan total fenol pada wedang uwuh ready to drink. Setelah didapatkan kombinasi waktu dan suhu pasteurisasi yang terbaik, selanjutnya dilakukan analisa kandungan total fenol selama penyimpanan. Serta diamati juga pertumbuhan bakteri yang terdapat di dalam wedang uwuh selama penyimpanan. Wedang uwuh dengan perlakuan suhu dan waktu pasteurisasi terbaik disimpan pada suhu dingin $\left(8-10^{\circ} \mathrm{C}\right)$ selama 20 hari dan setiap 5 hari sekali diuji kadar total fenol dan dihitung jumlah pertumbuhan bakteri selama penyimpanan.

\section{Analisa Statistik}

Data dianalisa menggunakan One Way ANOVA. Bila ada beda nyata dilanjutkan dengan uji beda nyata menggunakan DMRT pada taraf signifikansi $5 \%$.

\section{HASIL DAN PEMBAHASAN}

\section{Total Fenol}

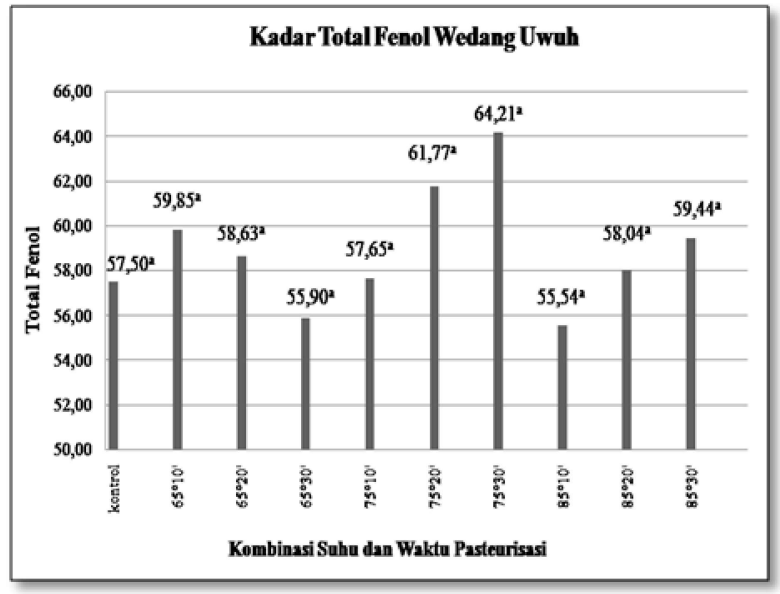

Gambar 1. Total Fenol Wedang Uwuh dalam Berbagai Perlakuan

$\begin{array}{lllll}* \text { Nilai } & \text { yang } & \text { diikuti } & \text { oleh huruf } & \text { yang } \\ \text { sama } & \text { pada } & \text { grafik } & \text { menunjukkan } & \text { nilai }\end{array}$ tidak berbeda nyata $(\alpha=5)$

Berdasarkan Gambar 1 nilai kadar total fenol kontrol (tanpa perlakuan pasteurisasi) mempunyai kadar total fenol sebesar 57,50 ppm. Pada pengamatan kadar total fenol wedang uwuh pasteurisasi suhu $65^{\circ} \mathrm{C}$ dan waktu 10 menit, 20 menit, dan 30 menit secara berturut-turut adalah 59,85 ppm; 58,63 ppm; dan 55,90 ppm. Sedangkan analisa total fenol pada pasteurisasi suhu $75^{\circ} \mathrm{C}$ dan waktu 10 menit, 20 menit, dan 30 menit secara 
berturut-turut adalah sebesar 57,65 ppm; 61,77 ppm; dan 64,21 ppm. Serta pada pasteurisasi suhu $85^{\circ} \mathrm{C}$ dengan waktu 10 menit, 20 menit, dan 30 menit secara berturut-turut adalah 55,54 ppm; 58,04 ppm; dan 59,44 ppm.

Hasil pengukuran total fenol wedang uwuh dianalisis secara statistik dengan menggunakan analisis ragam (ANOVA) selang kepercayaan 95\%. Hasil pengolahan statistik data hasil pengukuran total fenol dapat dilihat pada Lampiran. Data hasil pengolahan analisis ragam menunjukkan bahwa nilai signifikansi sampel adalah 0.206 sedangkan nilai signifikansi level adalah 0.05 . Nilai signifikansi sampel yang lebih besar daripada nilai signifikansi level menunjukkan bahwa pada selang kepercayaan 95\%, sampel wedang uwuh yang diujikan tidak berbeda nyata antara berbagai perlakuan. Kadar total fenol wedang uwuh "ready to drink" dengan berbagai kombinasi perlakuan suhu dan waktu pasteurisasi, berkisar antara 55,54 - 64,21 ppm.

Kinetika Perubahan Total Fenol Selama Penyimpanan

Tabel 1. Total Fenol Selama Penyimpanan

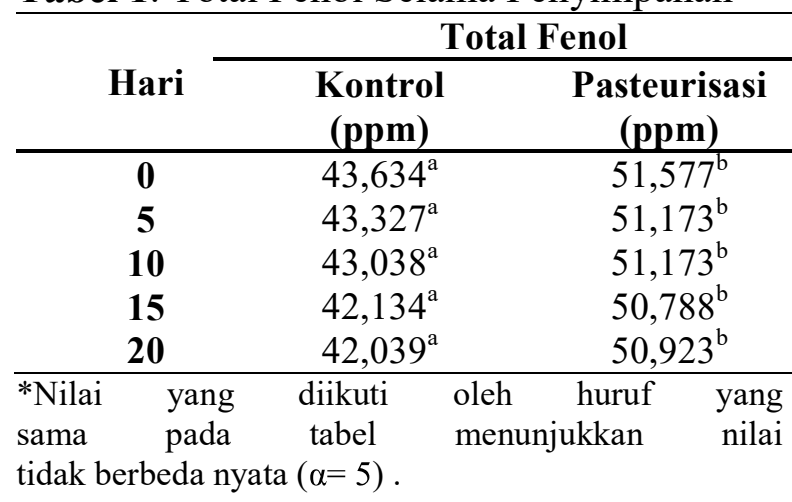

Nilai signifikansi sampel wedang uwuh yang lebih besar daripada nilai signifikansi level menunjukkan bahwa pada selang kepercayaan 95\%, sampel wedang uwuh yang diujikan tidak berbeda nyata. Semua kombinasi suhu dan waktu pasteurisasi pada dasarnya tidak menunjukkan perbedaan yang signifikan. Sehingga semua perlakuan dapat digunakan untuk pengamatan kinetika perubahan kadar total fenol.

Dalam hal ini, peneliti memilih kombinasi suhu pasteurisasi $75^{\circ} \mathrm{C}$ dan waktu
30 menit, pemilihan tersebut berdasarkan penelitian pendahuluan yang dilakukan oleh Sukasih, dkk (2009). Dalam penelitiannya, Sukasih, dkk melakukan pengamatan jumlah mikroba pada santan yang dipasteurisasi dengan beberapa perlakuan suhu dan waktu pasteurisasi. Dari hasil pengamatan tersebut diperoleh hasil bahwa santan yang dipasteurisasi pada suhu $65^{\circ} \mathrm{C}$ masih terdapat mikroba sebesar 1,3 x $10^{4}$ koloni $/ \mathrm{ml}$, sedangkan santan yang dipasteurisasi pada suhu $75,80,85$, dan $90^{\circ} \mathrm{C}$ jumlah mikroba yang terdapat pada santan adalah nol (0).

Berdasarkan hasil pengamatan tersebut, maka dipilih suhu pasteurisasi $75^{\circ} \mathrm{C}$. Wedang uwuh cup yang telah dipasteurisasi pada suhu $75^{\circ} \mathrm{C}$ selama 30 menit disimpan pada penyimpanan suhu dingin $\left(8-10^{\circ} \mathrm{C}\right)$ selama 20 hari dan setiap 5 hari sekali diuji kadar total fenolnya

Berdasarkan Tabel 1, pengamatan perubahan total fenol selama penyimpanan menunjukkan penurunan yang tidak signifikan. Penurunan total fenol selama penyimpanan tidak berbeda nyata dari hari ke-0 sampai pada hari ke-20.

Penurunan total fenol selama penyimpanan pada sampel wedang uwuh yang tidak dipasteurisasi (kontrol) dari hari ke-0 sampai hari ke-20 yaitu dari 43,634 ppm menjadi 42, 039 ppm, sedangkan pada sampel wedang uwuh yang telah dipasteurisasi pada suhu $75^{\circ} \mathrm{C}$ selama 30 menit mengalami penurunan total fenol dari hari ke-0 sebesar 51,577 ppm menjadi 50,923 ppm pada hari ke-20.

Kemudian hasil pengukuran perubahan total fenol wedang uwuh dari hari ke-0 sampai hari ke-20 dianalisis secara statistik dengan menggunakan analisis ragam (ANOVA) selang kepercayaan $95 \%$.

Pada selang kepercayaan 95\%, sampel wedang uwuh yang diujikan tidak berbeda nyata dari hari ke-0 sampai hari ke-20. Ini artinya selama penyimpanan 20 hari, wedang uwuh tidak mengalami penurunan kadar total fenol yang signifikan.

Penurunan kandungan total fenol dalam suatu bahan dapat disebabkan terjadinya oksidasi senyawa fenolik oleh udara atau karena aktifitas enzim polyfenol oksidase (PPO) di dalam bahan tersebut (Chilaka et al., 
2002). Senyawa polifenol teroksidasi akan membentuk senyawa quinone yang tidak terukur pada analisis total fenol. Oksidasi senyawa fenolik oleh PPO pada produk nabati menyebabkan perubahan warna produk menjadi kecoklatan dan dikenal dengan istilah browning (Kahn, 1975).

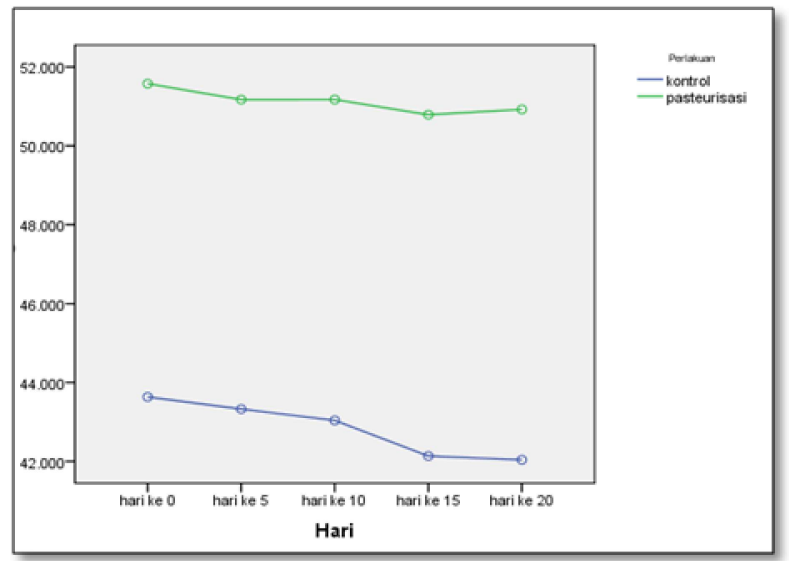

Gambar 2. Kinetika Perubahan Total Fenol Selama Penyimpanan

Keterangan :

$$
\begin{aligned}
& \text { = Sampel kontrol (tanpa perlakuan } \\
& \text { pasteurisasi) } \\
& =\text { Sampel Pasteurisasi suhu } 75^{\circ} \mathrm{C} \text { dan } \\
& \text { waktu } 30 \text { menit. }
\end{aligned}
$$

\section{Pertumbuhan Mikroba}

Berdasarkan ketentuan SNI batas maksimum angka lempeng total pada makanan dan minuman pasteurisasi dalam kemasan adalah sebanyak 1 x $10^{4}$ koloni $/ \mathrm{ml}$. Berdasarkan Tabel 2 dapat diamati bahwa jumlah bakteri pada minuman wedang uwuh yang tidak dipasteurisasi, mencapai angka 1 x $10^{4}$ koloni/ml berada diantara hari ke-5 dan hari ke-10. Sedangkan pertumbuhan mikroba pada wedang uwuh yang dipasteurisasi mencapai jumlah $1 \times 10^{4} \mathrm{koloni} / \mathrm{ml}$ berada diantara hari ke-10 dan hari ke-15. Untuk itu perlu dilakukan pendekatan secara matematika dengan cara interpolasi. Berdasarkan hasil interpolasi, pertumbuhan mikroba pada wedang uwuh yang tidak mengalami perlakuan pasteurisasi mencapai jumlah $1 \mathrm{x}$ $10^{4} \mathrm{koloni} / \mathrm{ml}$ sesuai ketentuan SNI pada hari ke-8, sedangkan pertumbuhan mikroba pada wedang uwuh yang diberi perlakuan pasteurisasi suhu $75^{\circ} \mathrm{C}$ selama 30 menit, mencapai jumlah mikroba 1 x $10^{4} \mathrm{koloni} / \mathrm{ml}$ pada hari ke-11. Berdasarkan hasil pengamatan tersebut membuktikan bahwa perlakuan pasteurisasi dapat menambah umur penerimaan produk pangan secara mikrobiologis. Perlakuan pasteurisasi suhu $75^{\circ} \mathrm{C}$ selama 30 menit pada wedang uwuh dapat menambah umur penerimaan produk secara mikrobiologis selama 3 hari.

Tabel 2. Pertumbuhan Mikroba

\begin{tabular}{ccc} 
& \multicolumn{2}{c}{ Jumlah Mikroba } \\
\cline { 2 - 3 } Hari & $\begin{array}{c}\text { Kontrol } \\
(\text { koloni } / \mathrm{ml})\end{array}$ & $\begin{array}{c}\text { Pasteurisasi } \\
(\text { koloni } / \mathrm{ml})\end{array}$ \\
$\mathbf{0}$ & $1,77 \times 10^{3}$ & $8,2 \times 10^{2}$ \\
$\mathbf{5}$ & $1,95 \times 10^{3}$ & $8,6 \times 10^{2}$ \\
$\mathbf{1 0}$ & $1,37 \times 10^{4}$ & $1,01 \times 10^{3}$ \\
$\mathbf{1 5}$ & $1,19 \times 10^{6}$ & $4,0 \times 10^{4}$ \\
$\mathbf{2 0}$ & $1,28 \times 10^{6}$ & $2,3 \times 10^{5}$ \\
\hline
\end{tabular}

Pasteurisasi adalah pemanasan produk pangan dengan suhu dan waktu tertentu. Pemanasan pada suhu pasteurisasi dimaksudkan untuk membunuh sebagian kuman patogenik yang ada dalam pangan, dengan seminimum mungkin kehilangan gizinya dan mempertahankan semaksimal mungkin sifat fisik dan cita rasa (Purnomo dan Adiono, 1987). Pengawetan dengan panas saat ini masih menjadi pilihan dengan alasan biaya yang lebih murah dan memerlukan teknologi yang sederhana, salah satunya adalah pasteurisasi. Pasteurisasi adalah proses pemanasan untuk memperpanjang umur simpan bahan pangan melalui pemanasan pada suhu di bawah $100^{\circ} \mathrm{C}$ yang bertujuan untuk membunuh mikroorganisme seperti bakteri, kapang dan khamir serta menginaktivasi enzim yang terdapat dalam bahan pangan itu sendiri dengan masih mempertimbangkan mutunya (Fellow, 1992).

Kombinasi suhu $75^{\circ} \mathrm{C}$ dan waktu 30 menit terbukti telah mengurangi jumlah mikroba dalam wedang uwuh, sehingga dapat menghambat pertumbuhan mikroba sampai hari ke-11 pada penyimpanan suhu rendah (8$\left.10^{\circ} \mathrm{C}\right)$. Proses pasteurisasi pada umumnya dikombinasikan dengan proses pengawetan lainnya seperti penyimpanan pada suhu rendah. Pada produk susu pasteurisasi mempunyai masa simpan tidak lebih dari 7- 
10 hari pada suhu $7^{\circ} \mathrm{C}$ (Forsythe dan Hayes, 1998).

\section{KESIMPULAN}

Variasi suhu dan waktu pasteurisasi tidak berpengaruh nyata terhadap kadar total fenol wedang uwuh. Semua kombinasi suhu dan waktu pasteurisasi dapat digunakan dalam pasteurisasi wedang uwuh ready to drink, karena berdasarkan Analisa Statistik tidak menunjukkan beda nyata antar kombinasi perlakuan pasteurisasi. Berdasarkan pengamatan kinetika perubahan kadar total fenol wedang uwuh, menunjukkan bahwa tidak terjadi penurunan kadar fenol yang signifikan dari hari ke-0 sampai hari ke-20.

\section{DAFTAR PUSTAKA}

Chilaka, Ferdinand C., Eze Sabinus, Anyadiegwu Clement and P.O. Uvere. 2002. Browning in processed yams: peroxidase or polyphenol oxidase. J. Sci. Food Agric. 82: 899-903.

Dulimarta, H.S. 2000. Kajian Stabilitas Beberapa Formulasi Bir Pletok (Minuman Khas Betawi) dan Pengaruhnya Selama Penyimpanan. Skripsi. Fakultas Teknologi Pertanian. IPB.

Fellow, P.J. 1992. Food Processing Technology. CRC Press. New York.

Forsythe, S.J. dan P.R., Hayes. 1998. Food Hygiene, Microbiology and HACCP. Aspen Publisher, Gaithersburg, Maryland.

Girsang, J. 2003. Kajian Formulasi Minuman Madai dari Rempah-rempah dan Pengaruhnya Selama Penyimpanan. Skripsi. Fakultas Teknologi Pertanian. IPB.

Girsang, J. 2003. Kajian Formulasi Minuman Madai dari Rempah-rempah dan Pengaruhnya Selama Penyimpanan. Skripsi. Fakultas Teknologi Pertanian. IPB.

Herold. 2007. Formulasi Minuman Fungsional Berbasis Kumis Kucing (Orthosiphon Aristatusbl. Miq) Yang Didasarkan Pada Optimasi Aktivitas Antioksidan, Mutu Citarasa Dan Warna.
Skripsi. Fakultas Teknologi Pertanian . Institut Pertanian Bogor.

Kahn, V. 1975. Polyphenol oxidase activity and browning of three avocado varieties, J. Sci Food Agric. 26: 1319-1324.

PDN. 2012. Arah Kebijakan 2012 : Potensi dan Sasaran Strategisnya. DITJEN PDN/MJL/01/2012.

Purnomo, H. dan Adiono. 1987. Ilmu Pangan. Cetakan Pertama. UI Press, Jakarta.

Sukasih, Erni. Prabawati, Sulusi. Hiadayat, Tatang. 2009. Optimasi Kecukupan Panas Pada Pasteurisasi Santan Dan Pengaruhnya Terhadap Mutu Santan Yang Dihasilkan. Jurnal Pascapanen. Vol 6. No 1.

Zulfahmi dan Nirmagustina, Dwi Eva. 2012. Pengaruh Sukrosa Terhadap Kandungan Total Fenol Minumasn Rempah Tradisional (Minuman Secang). Jurnal Penelitian Pertanian Terapan. Vol. 12. No 2. 